Original Article

\title{
BODY-SURFACE COMPOUNDS IN BUCKFAST AND CAUCASIAN HONEY BEE WORKERS (APIS MELLIFERA)
}

\author{
Aneta Strachecka ${ }^{1 *}$ \\ Grzegorz Borsuk ${ }^{1}$ \\ Jerzy Paleolog ${ }^{1}$ \\ Krzysztof Olszewski ${ }^{1}$ \\ Milena Bajda ${ }^{1}$ \\ Jacek Chobotow ${ }^{2}$ \\ 'Department of Biological Basis of Animal Production, \\ Faculty of Biology and Animal Breeding, University of Life Sciences in Lublin, \\ Akademicka 13, 20-950 Lublin, Poland \\ 2Department of Zoology, Institute of Biology and Biochemistry \\ Museum Zoological/Laboratory, Faculty of Biology and Biotechnology, \\ Akademicka 19, 20-033 Lublin, Poland \\ *corresponding author: aneta.strachecka@up.lublin.pl \\ Received 26 November 2012; accepted 21 February 2014
}

\begin{abstract}
Body-surface chemical compounds were studied in 1-day-old nest workers and foragers both in Buckfast and Caucasian bees. The workers of these two age-castes were sampled twice in each of two consecutive years. Body-surface lipids were determined by means of gas chromatography, with a GCQ mass spectrometer. Protein concentrations and activities on the body surface were examined in bee cuticle rinsings obtained from worker bees according to the methods of Lowry, of Anson, and of Lee and Lin. Protease and protease inhibitor activities were determined. Polyacrylamide gel electrophoresis was performed. Caucasian bees, particularly foragers, had more lipids, but Buckfast bees (two age-castes) had more proteins on their body surfaces. A total of 17 alkane types (C17 - C33), 13 alkene types (C21 - C33), 21 esters (C12 - C32), and a phenol (C14) were detected in both races. Alkene $\mathrm{C} 33$ was detected only in Caucasian bees. More alkanes, esters, and phenols were found in Caucasian 1-day-old nest workers and foragers than in these age-castes of Buckfast bees. The protein concentration and protease inhibitor activities were lower in Caucasian bees that had higher protease activities. These values corresponded with specific numbers and widths of the electrophoretic bands.
\end{abstract}

Keywords: Apis mellifera, chromatography (GC/MS), cuticle surface, lipid, protein, proteolysis.

\section{INTRODUCTION}

The protective cuticle barrier in insects is the first line of defense against pathogens (Andersen, 1979). Many biochemical reactions proceed on the body surface of bees, e.g., sclerotization, melanization, and chitinization (Sugumaran, 2002; Merzendorfer and Zimoch, 2003; Evans et al., 2006; Burzyński et al., 2013). During these and other processes, which also occur in hemolymph or midgut, several chemical compounds are secreted on the chitinous carapace (Evans et al., 2006).
The first group consists of the lipids, which are responsible for both water repelling and transpiration, as well as functioning as pheromones or protecting bees against harmful environmental influences. The body-surface lipids usually contain hydrocarbons, waxy esters (long-chain alcohol esters of long-chain acids), primary alcohols, and fatty acids (Kolattukudy, 1968; Jackson and Baker, 1969; Plattner and Spencer, 1983; Howard and Lord, 2003; Buckner et al., 2009). These chemical compounds are also present on the surface of honey bee eggs (Arnold et al., 1996; Martin et al., 2002; Katzav-Gozansky 
et al., 2003). Hydrocarbons are associated with lipophorins, which are multifunctional lipid carriers for phospholipids, diacylglycerols, and sterols as the cuticle evolves (Howard and Blomquist, 1982; Pho et al., 1996; Buckner et al., 2009). Phenols, which appear after ecdysis, also participate in cuticle layer formation. They are associated with the epicuticular filaments in both epicuticle and presumptive epicuticle (Locke and Krishnan, 2008). The surface esters, originally called "brood esters," are important sociochemicals within the colony (Keeling and Slessor, 2005).

The second group consists of the body-surface proteins, particularly proteases and protease inhibitors. To date, serine proteases, cysteine proteases, asparagine proteases, and metalloproteases have been found in bees (Grzywnowicz et al., 2009; Strachecka et al., 2011; 2012a,b,d,e). These enzymes safeguard the insects against infections and help maintain the homoeostasis of the apian body (Brownless and Williams, 1993; Gorman and Paskewitz, 2001), which depends, however, on the environment pollution level or application of common chemotherapeutics (Strachecka et al., 2010; 2012a,b,d).

Races of bees are discriminated on the basis of morphological and genetic markers, as well as hemolymph enzyme polymorphisms (De la Rua et al., 2009). Surface hydrocarbons help differentiate certain insect species, e.g., in Nasutitermes (N. costalis and N. ephratae; (Haverty et al., 1990) or honey bees (Africanized and European; Carlson and Bolten, 1983; Lavine et al., 1988; Lavine and Vora, 2005). An interesting hypothesis is that there is also interracial variability in apian cuticle chemical compounds. On the other hand, if the system of body-surface chemical compounds is susceptible to natural selection pressure, then it should be different in different races of bees. Therefore, the goal of the present research was to determine the body-surface chemical compounds and their interracial variability in 1-day-old nest workers and foragers in Buckfast versus Caucasian bees.

\section{MATERIAL AND METHODS}

The research was conducted on purebred Buckfast and Caucasian bees; 10 colonies in two consecutive seasons of 2010/2011 and 2011/2012 (10 colonies $\times 2$ genotypes: Buckfast/Caucasian $\times 2$ seasons). The colonies were headed by queens that had been instrumentally inseminated with the semen of single drones. Ten 1-day-old nest workers and ten foragers (different age-castes) were sampled from each colony once a season and pooled within each genotype and season to create 4 groups of 200 bees each; i.e., Buckfast foragers, Caucasian foragers, Buckfast 1-day-old workers, and Caucasian 1-day-old workers. Then, the body surfaces of 40 living bees from each of the 4 groups were analyzed by means of gas chromatography with a GCQ mass spectrometer (Thermo-Finnigan USA). Components (mostly lipids) were characterized by their individual mass spectra, which were compared to standards and matched by means of a computer search with an IBM-PC version of the NIST/EPA/NIH Mass Spectral Database.

Additionally, 3 samples comprising 101 -day-old nest workers and 3 samples of 10 foragers each were collected twice a season from each colony within each genotype ( 2 worker age-castes $\times 3$ samples $x 10$ colonies $\times 2$ genotypes $\times 2$ repetitions $\times$ 2 seasons). The material was frozen in sterile bags at $-8^{\circ} \mathrm{C}$ and stored for $1-2$ months. Then, the samples were successively refrozen and rinsed in $10 \mathrm{~mL}$ distilled water for $20 \mathrm{~s}$ to remove impurities. Proteins were not found in the rinsings using the Lowry method, as modified by Schacterle and Pollack (1973). Therefore, the rinsings were discarded. Subsequently, samples were shaken/rinsed for 4 min at $3400 \mathrm{rpm}$ in $10 \mathrm{~mL}$ distilled water (hydrophilic proteins) and then in a $1 \%$ detergent solution (Triton $X-100)$ in distilled water $(10 \mathrm{~mL})$. The solutions obtained from each sample were then divided into 3 portions, poured into 3 respective Eppendorf tubes, and frozen again at $-40^{\circ} \mathrm{C}$. The procedure produced a $2 \mathrm{~mL}$ sample that was used for determining protease and protease inhibitor activities (portion-a); $2 \mathrm{~mL}$ used for electrophoretic assays (portion-b); and $2 \mathrm{~mL}$ kept as reserve (portion-c).

The procedure resulted in a total of 2880 portions (480 samples $\times 2$ rinsings $\times 3$ portions). Portions were analyzed as follows: general protein content by the Lowry method, as modified by Schacterle and Pollack (1973); proteolytic activity in relation to the substrates (gelatin, hemoglobin, ovoalbumin, albumin, cytochrome C, casein) according to methods described by Anson (1938) and modified by Strachecka et al. (2011), with albumin selected for further study as the optimum substrate; activities of proteases according to the modified Anson (1938) method; and levels of natural protease inhibitors based on the Lee and Lin (1995) method.

Polyacrylamide gel electrophoresis was performed using portions-b, which had been previously lyophilized and then combined with $100 \mu$ distilled water. 
The following analyses were conducted: protease detection using the Laemmli (1970) method, and detection of inhibitors of asparagine and serine proteases using the modified Felicioli et al. (1997) method.

Multivariate general linear model (GLM) was carried out, allowing for the following factors: genotypes (Buckfast/Caucasian), age-castes, seasons, and colonies. Season and colony impact proved insignificant. Therefore, genotype and age-caste means were compared, using two-way ANOVA (genotypes $\times$ age-caste) and Tukey's test (SAS Institute Version 9.13., 2002-2003 license 86636).

\section{RESULTS}

Proteins and lipids were detected in both genotypes and both of the age-castes (Tab. 1). In general, Caucasian bees, particularly foragers, had more lipids, but Buckfast bees had more proteins on their body surfaces (Tab. 1 and 2). Four types of lipid compounds were found on bee cuticle: 17 alkane types (C17 - C33), 13 alkene types (C21 - C33), 21 esters (C12 - C32), and a phenol (C14) (Fig. 1 and 2). Alkene C33 was detected only in Caucasian bees, and the remaining chemical compounds were present on worker cuticles in both bee genotypes. The compound quantities were, however, different between Caucasian and Buckfast bees. More esters were found in Caucasians, but more alkenes were detected in Buckfast workers, independently of the age-caste (Tab. 1; Fig. 1 and 2). Consequently, there were no significant age-caste $\times$ breed interactions $(P>0.1)$. The Caucasian foragers had more bodysurface alkanes and phenols than the Buckfasts, which was not observed, however, in 1-day-old nest workers. Consequently, there were significant breed $x$ age-caste interactions $(P<0.01)$ in this case.

Although the protein concentration (Tab. 1) was lower in Caucasian bees, they had higher protease activities than the Buckfasts. These differences were observed both in foragers and 1-day-old nest workers. On the other hand, the body-surface protease inhibitors had similar activities in foragers in both genotypes whereas in 1-day-old Buckfast workers, the inhibitors were more active than in the Caucasians. Thus, Caucasian bees had a greater capacity for proteolysis than for its inhibition.

Foragers had lower esters and more alkenes than 1-day-old nest workers. Otherwise, these age-castes did not differ, and genotypes had no significant influence in the case of the lipid compounds. On the other hand, 1-day-old workers had significantly larger protein concentration and protease activities but lower protease inhibitor activities. These relationships were evident in both genotypes. Thus, the age caste markedly influenced the protein concentration and the cuticle proteolytic system activity.

The electrophoretic images (Tab. 3, Fig. 3) correspond with the above results because higher band numbers and larger band widths were found at higher protein concentrations/higher protease activities/higher protease inhibitor activities.

\section{DISCUSSION}

Our studies have shown that the outermost layer of the apian cuticle is composed of alkanes, alkenes, esters, phenols, and proteins but that the amounts of some of these chemical compounds as well as body-surface enzyme activities differ in Buckfast and Caucasian workers. Caucasian bees have more lipids, which is particularly apparent in foragers, but Buckfast bees (two age-castes) have more proteins. This difference could be accounted for by the large amounts of propolis gathered by the Caucasian bees. Consequently, there is chemical interracial variability in apian body surface. Worth mentioning are esters, alkenes, and proteins, including proteases, because these chemical compounds had different amounts/ activity in Buckfast and Caucasian workers independently of age-caste. Surface hydrocarbons have been used for species discrimination in Nasutitermes (Haverty et al., 1990), and Africanized and European honey bees (Carlson and Bolten, 1983; Lavine et al., 1988; Lavine and Vora, 2005). Our results showed that these substances also may be taken into consideration for race/breeding line discrimination (De la Rua et al., 2009) or the interpretation of evolutionary A. mellifera race histories (Chapuisat, 2014). Foragers appeared to be the best material for the interracial variability studies with the use of lipids; we found distinct interracial differences in all lipid compound groups in this age-caste.

The higher cuticle lipid fraction in Caucasian bees could be connected with a higher water content in their tissues (Hadley, 1981; Muszyńska, 1988), which may result in lower resistance during overwintering in bees containing more water (Muszyńska, 1988). This concept corresponds with Olszewski's (2007) findings that Buckfasts are more resistant than Caucasians to adverse winter weather conditions. Thus, the lipid fraction concentration could be a factor in the natural selection of overwintering bees and therefore might have been modified during the evolution of bees. C33 alkanes seemed to be of particular importance 
Table 1. Chemical compounds detected on the cuticles of 1-day-old workers and foragers in Buckfast (Bcf) and Caucasian (Cau) bees

\begin{tabular}{|c|c|c|c|c|}
\hline & & Bcf & Cau & Overall mean \\
\hline & Compound type & Mean \pm SD & Mean \pm SD & \\
\hline & $\begin{array}{c}\text { Line alkanes, branched alkanes, } \\
\text { methyl alkanes (\%) }\end{array}$ & $1.38 \pm 0.07$ & $1.46 \pm 0.02$ & $1.42 \pm 0.05$ \\
\hline$\tilde{a}$ & Alkenes (\%) & $1.30^{\mathrm{a}} \pm 0.07$ & $1.03^{\mathrm{b}} \pm 0.01$ & $1.30^{n} \pm 0.04$ \\
\hline & Esters (\%) & $2.75^{b} \pm 0.15$ & $3.53^{a} \pm 0.05$ & $2.63^{\mathrm{m}} \pm 0.09$ \\
\hline 3 & Phenols (\%) & $0.18 \pm 0.01$ & $0.19 \pm 0.01$ & $0.11 \pm 0.06$ \\
\hline 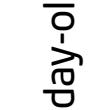 & $\begin{array}{c}\text { Proteins (concentration C; mg/ } \\
\mathrm{mL} \text { ) }\end{array}$ & $0.64 \pm 0.04$ & $0.48 \pm 0.12$ & $0.56^{m} \pm 0.08$ \\
\hline & Proteases (activity; as U/mg) & $11.68^{b} \pm 0.05$ & $29.97^{a} \pm 0.36$ & $\begin{array}{c}20.82^{\mathrm{m}} \pm \\
0.20\end{array}$ \\
\hline & $\begin{array}{c}\text { Protease inhibitors (activity; as } \\
\text { U/mg) }\end{array}$ & $6.70^{\mathrm{a}} \pm 0.17$ & $2.57^{b} \pm 0.19$ & $4.64^{n} \pm 0.18$ \\
\hline & $\begin{array}{c}\text { Line alkanes, branched alkanes, } \\
\text { methyl alkanes (\%) }\end{array}$ & $1.36^{\mathrm{b}} \pm 0.08$ & $2.05^{a} \pm 0.03$ & $1.41 \pm 0.09$ \\
\hline & Alkenes (\%) & $1.86^{a} \pm 0.10$ & $1.67^{b} \pm 0.02$ & $1.86^{\mathrm{m}} \pm 0.06$ \\
\hline & Esters (\%) & $2.14^{\mathrm{b}} \pm 0.12$ & $2.43^{a} \pm 0.04$ & $2.06^{n} \pm 0.07$ \\
\hline 苋 & Phenols (\%) & $0.05^{\mathrm{b}} \pm 0.01$ & $0.13^{a} \pm 0.01$ & $0.09 \pm 0.03$ \\
\hline 윤 & $\begin{array}{c}\text { Proteins (concentration C; mg/ } \\
\mathrm{mL} \text { ) }\end{array}$ & $0.36^{a} \pm 0.02$ & $0.07^{\mathrm{b}} \pm 0.01$ & $0.22^{n} \pm 0.02$ \\
\hline & Proteases (activity; as U/mg) & $7.03^{\mathrm{b}} \pm 0.03$ & $14.04^{a} \pm 0.28$ & $10.53^{n} \pm 0.15$ \\
\hline & $\begin{array}{c}\text { Protease inhibitors (activity; as } \\
\text { U/mg) }\end{array}$ & $7.99 \pm 0.03$ & $7.97 \pm 0.38$ & $7.98^{m} \pm 0.21$ \\
\hline & $\begin{array}{l}\text { Line alkanes, branched alkanes, } \\
\text { methyl alkanes (\%) }\end{array}$ & $1.37^{a} \pm 0.11$ & $1.75^{\mathrm{b}} \pm 0.07$ & \\
\hline & Alkenes (\%) & $1.58^{\mathrm{a}} \pm 0.12$ & $1.35^{\mathrm{b}} \pm 0.11$ & \\
\hline & Esters (\%) & $2.45^{a} \pm 0.14$ & $2.98^{b} \pm 0.08$ & \\
\hline 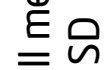 & Phenols (\%) & $0.12 \pm 0.09$ & $0.16 \pm 0.06$ & \\
\hline 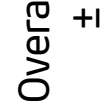 & $\begin{array}{c}\text { Proteins (concentration C; mg/ } \\
\mathrm{mL} \text { ) }\end{array}$ & $0.50^{\mathrm{a}} \pm 0.03$ & $0.28^{b} \pm 0.09$ & \\
\hline & Proteases (activity; as U/mg) & $9.36^{a} \pm 0.17$ & $22.00^{\mathrm{b}} \pm 0.22$ & \\
\hline & $\begin{array}{c}\text { Protease inhibitors (activity; as } \\
\text { U/mg) }\end{array}$ & $7.34^{\mathrm{a}} \pm 0.25$ & $5.27^{b} \pm 0.23$ & \\
\hline
\end{tabular}

a, b - Differences are statistically significant for comparisons between Bcf and Cau means ( $\mathrm{P} \leq 0.05)$. $\mathrm{m}, \mathrm{n}$-Differences are statistically significant for comparisons between overall means calculated for foragers and 1-day-old workers $(P \leq 0.05) ; S D$ - standard deviation.

Shaded fields relate to values significantly higher than unshaded values.

The amounts of non-protein chemical compounds were calculated from the peak sizes in GC/MS. Protease and protease inhibitor activities were calculated from the Anson (1938) formula. 


\section{J. APPC. SCL. VOL. 58 N NO. 12014}

Table 2.

The percentage of individual compounds in the lipid fraction in 1-day-old Buckfast/Caucasian workers and Buckfast/Caucasian foragers (Bcf/Cau)

\begin{tabular}{ccccc}
\hline \multirow{2}{*}{ Compound type } & \multicolumn{2}{c}{ Foragers } & \multicolumn{2}{c}{ 1-day-old workers } \\
\cline { 2 - 5 } & Bcf & Cau & Bcf & Cau \\
\hline $\begin{array}{c}\text { Line alkanes, branched } \\
\text { alkanes, methyl alkanes }\end{array}$ & 25 & 31 & 31 & 29 \\
\hline Alkenes & 33 & 24 & 21 & 17 \\
\hline Esters & 42 & 45 & 48 & 54 \\
\hline Phenols & 0.05 & 0.13 & 0.18 & 0.19 \\
\hline
\end{tabular}

Table 3.

PAGE zymography of proteins and the activity of proteases and protease inhibitors on the body surface of 1-day-old workers and foragers in Buckfast (Bcf) and Caucasian (Cau) bees

\begin{tabular}{|c|c|c|c|c|c|c|c|c|c|}
\hline \multirow[b]{3}{*}{ Substance } & \multirow[b]{3}{*}{$\mathrm{pH}$} & \multicolumn{4}{|c|}{ Foragers } & \multicolumn{4}{|c|}{ 1-day-old workers } \\
\hline & & \multicolumn{2}{|c|}{ Bcf } & \multicolumn{2}{|c|}{ Cau } & \multicolumn{2}{|c|}{ Bcf } & \multicolumn{2}{|c|}{ Cau } \\
\hline & & $\begin{array}{c}\text { Band } \\
\text { number }\end{array}$ & OD & $\begin{array}{c}\text { Band } \\
\text { number }\end{array}$ & OD & $\begin{array}{c}\text { Band } \\
\text { number }\end{array}$ & $\mathrm{OD}$ & $\begin{array}{c}\text { Band } \\
\text { number }\end{array}$ & $\mathrm{OD}$ \\
\hline \multirow{3}{*}{ Proteins } & 2.4 & 5 & 0.21 & 4 & 0.25 & 4 & 0.26 & 4 & 0.23 \\
\hline & 7.0 & 6 & 0.31 & 5 & 0.23 & 6 & 0.21 & 5 & 0.21 \\
\hline & 11.2 & 5 & 0.35 & 4 & 0.28 & 6 & 0.28 & 6 & 0.23 \\
\hline \multirow{3}{*}{ Proteases } & 2.4 & 5 & 0.32 & 8 & 0.39 & 9 & 0.29 & 9 & 0.32 \\
\hline & 7.0 & 3 & 0.30 & 6 & 0.35 & 4 & 0.33 & 6 & 0.43 \\
\hline & 11.2 & 4 & 0.21 & 5 & 0.22 & 4 & 0.26 & 6 & 0.29 \\
\hline \multirow{3}{*}{$\begin{array}{l}\text { Protease } \\
\text { inhibitors }\end{array}$} & 2.4 & 4 & 0.21 & 4 & 0.11 & 4 & 0.23 & 2 & 0.18 \\
\hline & 7.0 & 4 & 0.26 & 4 & 0.24 & 6 & 0.27 & 5 & 0.21 \\
\hline & 11.2 & 4 & 0.30 & 4 & 0.29 & 4 & 0.16 & 3 & 0.15 \\
\hline
\end{tabular}

OD - width of the bands (mm).

The results for protease activities in PAGE zymography are arithmetic means of the results obtained for Bcf or Cau foragers and 1-day-old Bcf or Cau workers.

for bee race discrimination because they were present only in Caucasian bees. C33 alkanes are biologically very active. They are identified as the major components of the homosexual courtshipstimulating pheromone blend in Drosophila melanogaster (Schaner et al., 1989). These compounds are responsible for inducing male fly copulatory behavior in Stomoxy calcitrans (Sonnet et al., 1979). High amounts of C33 alkanes were detected on worker body-surfaces, but amounts were low in queens in Friesella schrottkyi, and these compounds are elements of the aggressive pheromone (Nunes et al., 2010). Caucasian bees have a dysfunction of some type of the pheromone that triggers reproduction of varroa mites (Stort and Rebustini, 1998; Strachecka et al., 2012c, 2013), but they have more alarm pheromones than Buckfast bees (Harmon and VanEnglespdorp, 2004). Therefore, C33 alkenes may affect the specific behavior of Caucasian bees, which should be studied in the future.

Chain linear and/or branched alkanes, methylalkanes, and alkenes are common components of many insect surface lipids and in some species constitute more than $90 \%$ of this total fraction (Hadley, 1981). Our studies showed that this percentage was lower in bees, ranging from $52 \%$ to $58 \%$ in Buckfast bees and from $46 \%$ to $55 \%$ in Caucasian bees in the total of this fraction. Honeybees and dragonflies contain up to $58 \%$ of cuticular wax esters and phenols, having a total of 36-50 carbon atoms (Jacob and Hanssen, 1979; Patel et al., 2001). In our studies, Caucasian and Buckfast bees had respectively 45 


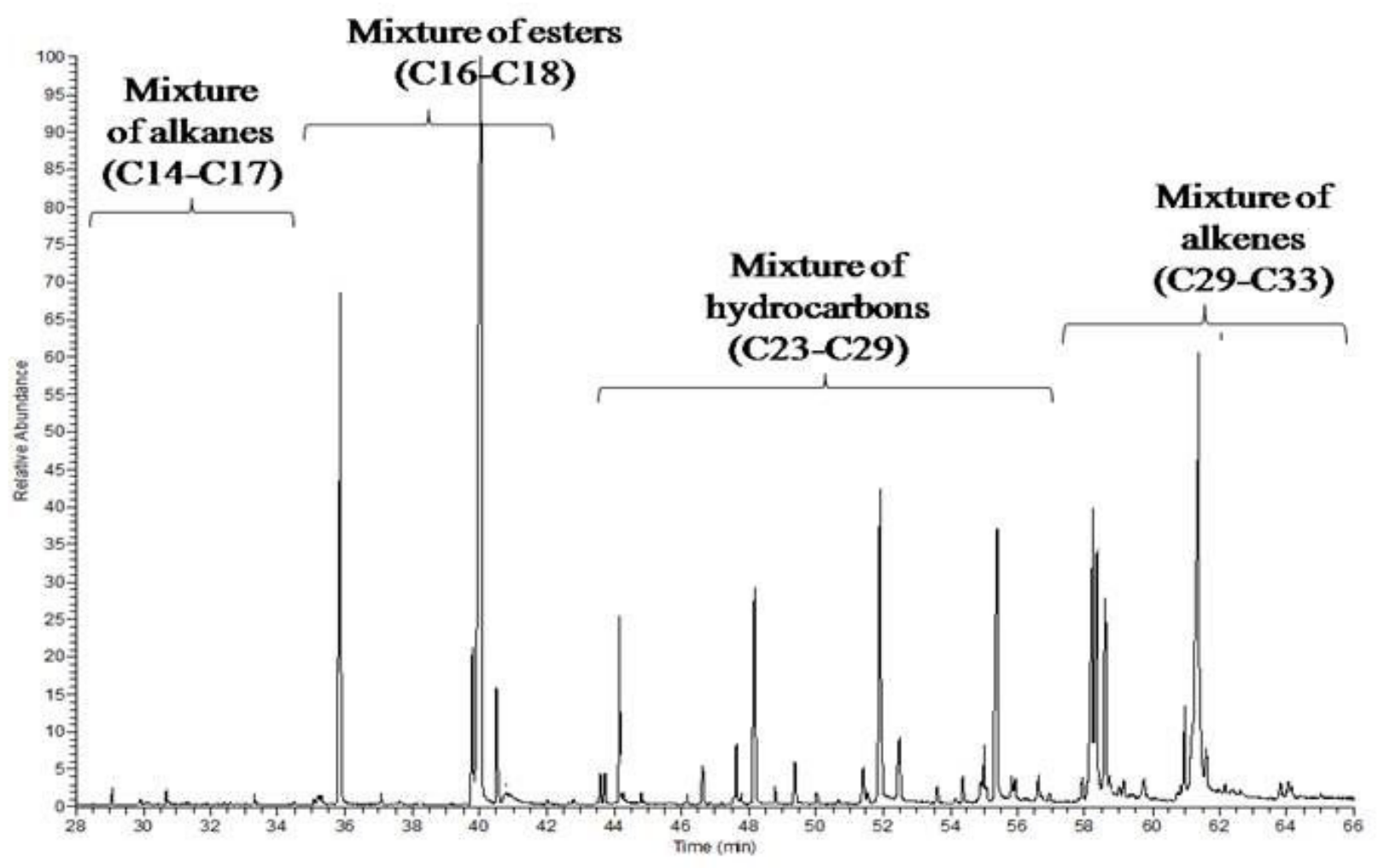

Bef

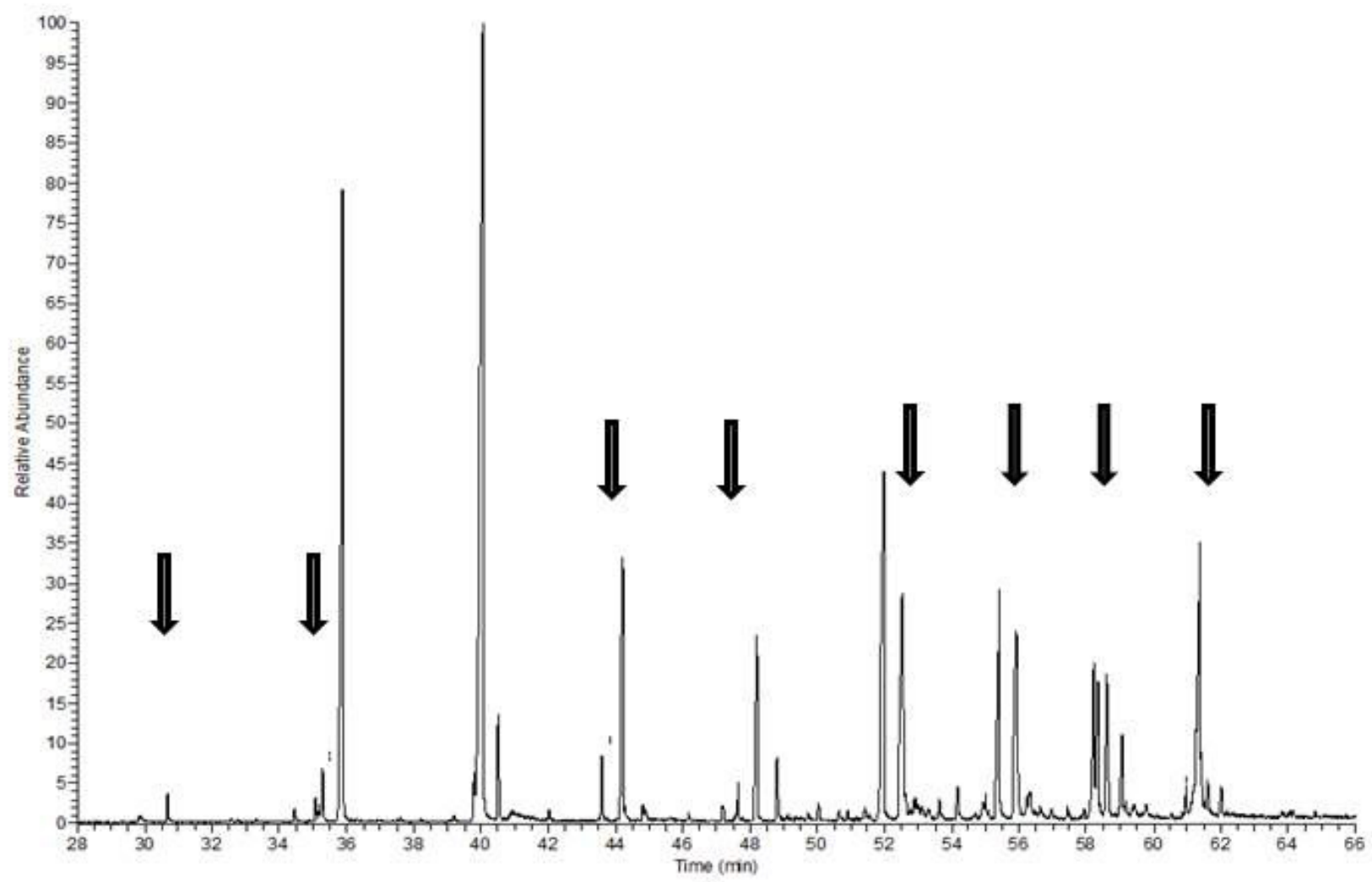

$\mathrm{Cau}$

Fig. 1. Chromatograms of the forager cuticle chemical compounds in Buckfast (Bcf) and Caucasian (Cau) bees. Arrows indicate differences between Bcf and Cau in numbers or sizes of peaks. 


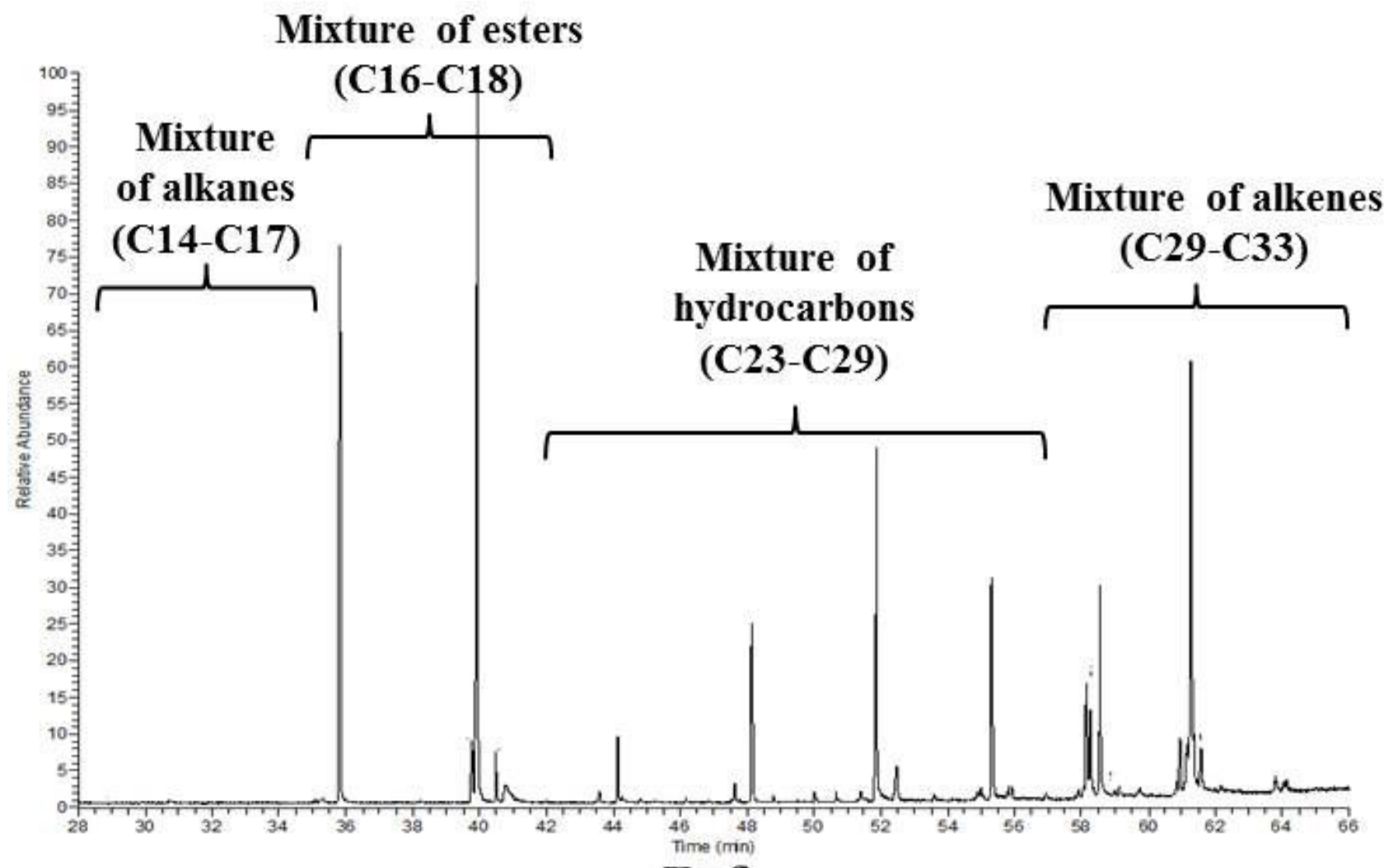

Bcf

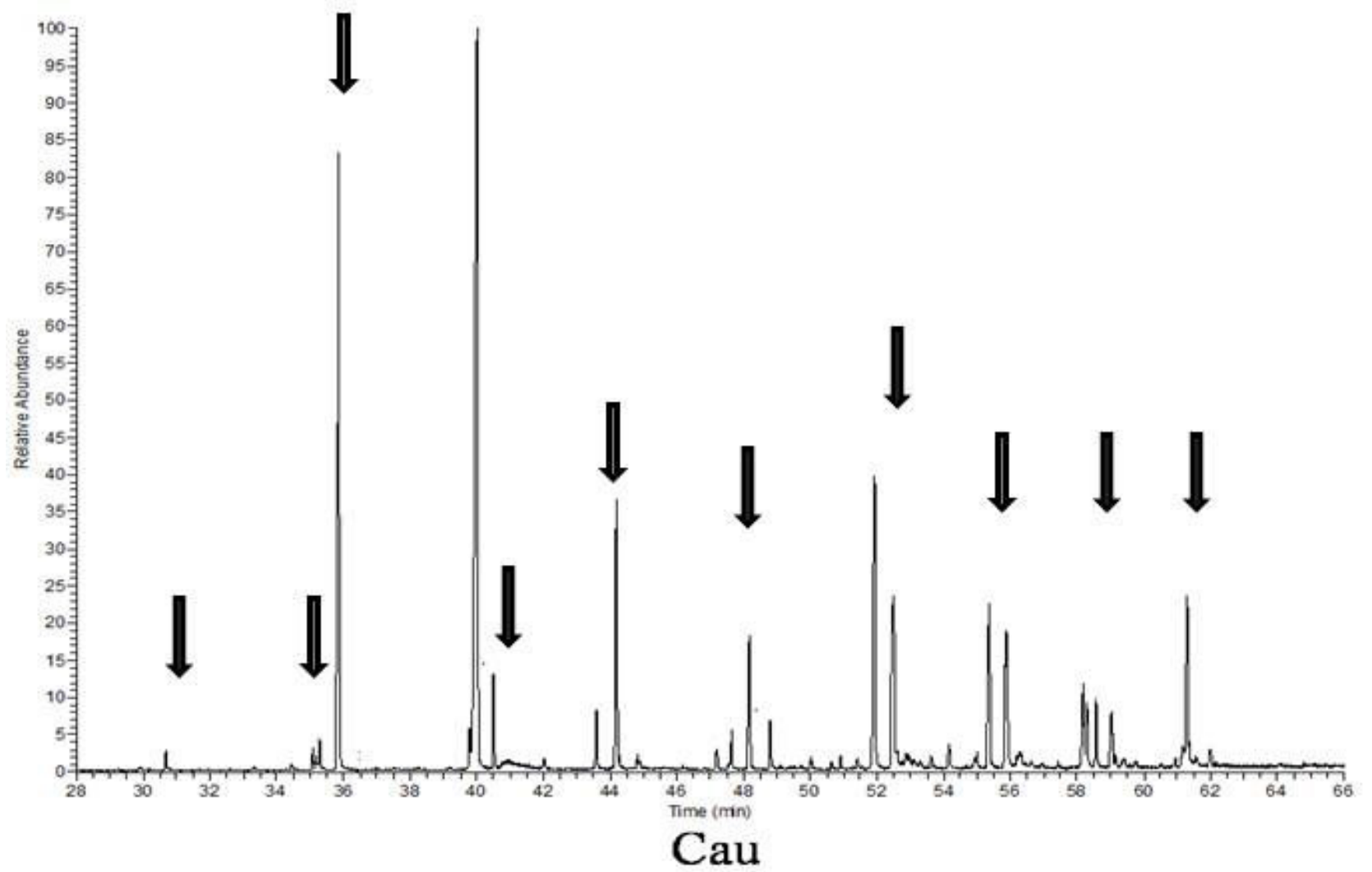

Fig. 2. Chromatograms of the 1-day-old worker cuticle chemical compounds in Buckfast (Bcf) and Caucasian (Cau) bees.

Arrows indicate differences between Bcf and Cau in numbers or sizes of peaks. 


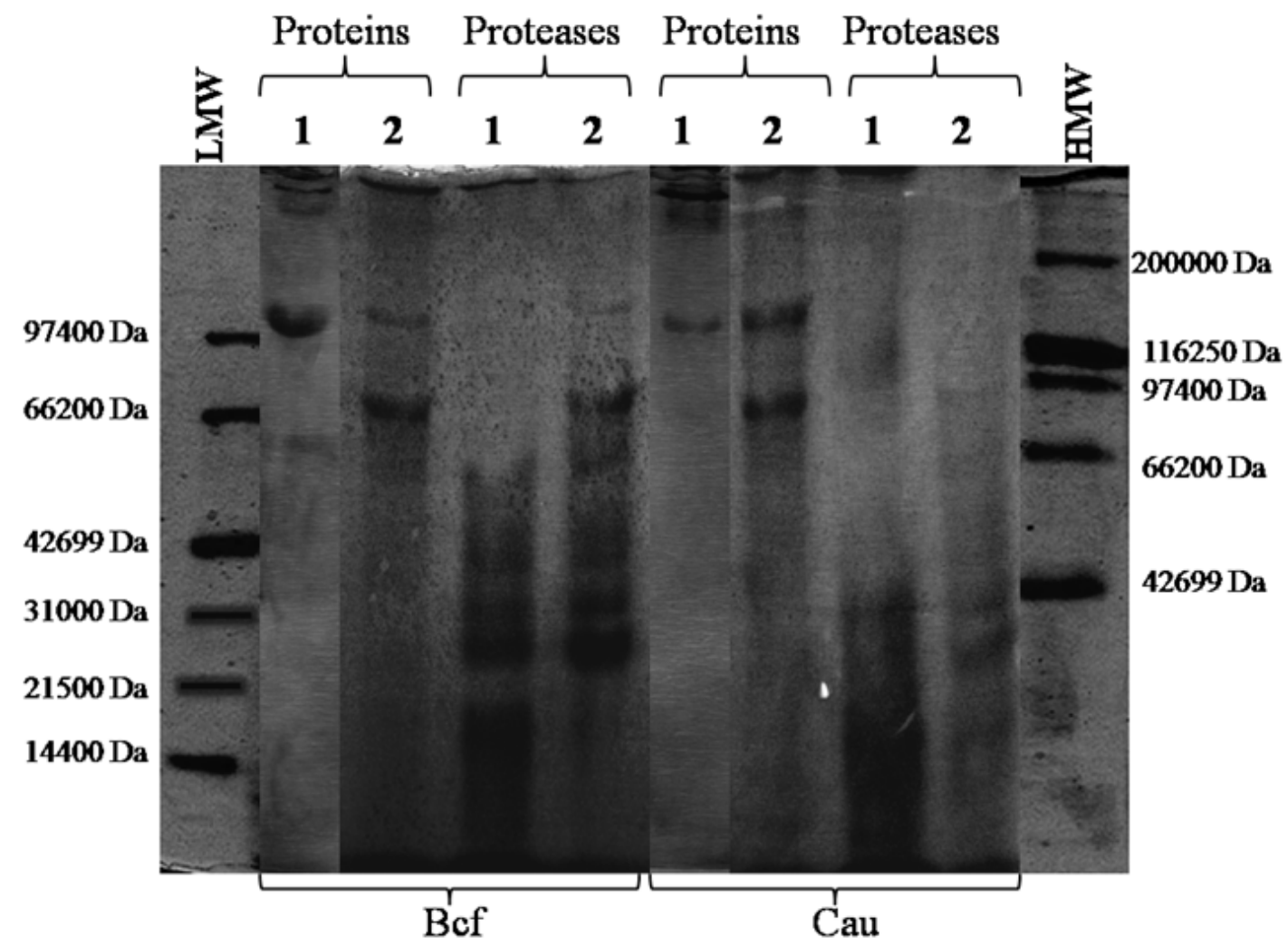

Fig. 3. Electrophorogram of cuticle protein concentrations and protease activities in Buckfast (Bcf) and Caucasian (Cau) 1-day-old workers (1) and foragers (2).

LMW - low-molecular standard; HMW - high-molecular standard.

- 54\% and 42 - 48\% of C12 - C32 esters on their cuticles. The esters, as pheromone constituents, could play a role in the competition of bees for the same food resources and in trail scenting (Jarau et al., 2006). These results do not correspond, however, with the low competitive abilities of the Caucasian foragers observed by Paleolog (2009). Our studies showed that Caucasian bees had more esters. They are a race that monitors a relatively larger area, and the insects move faster than Buckfasts from one nectarous plant to another (Konopacka, 1999; Borsuk and Olszewski, 2010; Olszewski et al., 2013). Buckfasts had higher cuticle-protein concentration, but Caucasian bee cuticles had a greater capacity for proteolysis and lower capacity for its inhibition. This proteolytic system is an element of cuticle-associated anti-pathogen resistance (Evans et al., 2006; Zou et al., 2006). How these results relate to the high resistance of Buckfasts to some pathogens (Brother Adam, 1983, 1993; Österlund, 1999) is difficult to say. Additional studies are needed.

\section{CONCLUSIONS}

Body-surface protein concentration and proteolytic activity may be taken into consideration during breed discrimination or studies of the evolutionary histories of bees because of distinct, age-caste-independent, interracial variability in these chemical compounds. Lipids also might be considered, but only in the forager age-caste. The C33 alkanes are the most appropriate chemical compounds with which to begin any such analysis.

The interracial variability in the lipid and protein cuticle cover could be caused by natural selection pressure.

\section{REFERENCES}

Andersen S. O. (1979) Biochemistry of insect cuticle. Annual Review of Entomology 24: 29-61. DOl: 10.1146/ annurev.en.24.010179.000333

Anson M. (1938) The estimation of pepsin, tripsin, papain and cathepsin with hemoglobin. The Journal of General Physiology 22: 79-84. 


\section{J. APRC. SCLI. VOL. 58 NO. 12014}

Arnold G., Quenet B., Cornuet J. M., Masson C., DeSchepper B., Estoup A., Gasquil P. (1 996) Kin recognition in honeybees. Nature 379: 498. DOl:10.1038/379498a0

Borsuk G., Olszewski K. (2010) Morphometric traits of Buckfast and Caucasian bees. Journal of Apicultural Science 54(1): 43-48.

Brother Adam (1983) Meine Betriebsweise. Ehrenwirt Verlag. München. 93 pp.

Brother Adam (1993) Hinweise über die Züchtung, Erhaltung und weitere Entwicklung der Buckfast-Biene. Imkerei-Technik-Magazin 4: 25-27.

Brownless J., Williams C. H. (1993) Peptidases, peptides and the mammalian blood-brain barrier. Journal of Neurochemistry 60: 780-793. DOl: 10.1111/j.14714159.1993.tb03223.x

Buckner J. S., Pitts-Singer T. L., Guèdot C., Hagen M. M., Fatland C. L., Kemp W. P. (2009) Cuticular lipids of female solitary bees, Osmia lignaria Say and Megachile rotundata (F.) (Hymenoptera: Megachilidae). Comparative Biochemistry and Physiology Part B 153: 200-205. DOl:10.1016/j.cbpb.2009.02.018

Burzyński S., Paleolog J., Patii S., Ilkowska-Musial E., Borsuk G., Olszewski K., Chittur S., Gupta V., Sarangi R., Strachecka A. (2013) Change gene expression and longevity in honeybees (Apis mellifera) fed with phenylbutyrate- and phenylacetylglutaminate- supplemented diet. Medycyna Weterynaryjna 69(12): 753-759.

Carlson D., Bolten A. (1983) Identification of Aricanized and European Honey Bees Using Extracted Hydrocarbons. Bulletin of the Entomological Society of America 30(2): 32-35.

Chapuisat M. (2014) Smells like queen since the cretaceous. Science 343: 254-255.

De la Rua P., Jaffe R., Dall Olio R., Munoz I., Serrano J. (2009) Biodiversity, conservation and current threats to European honeybees. Apidologie 40: 263-284. DOI: 10.1051/ apido/2009027

Evans J. D., Aronstein K., Chen Y. P., Hetru C., Imler J. L., Jiang H., Kanost M., Thompson G. J., Zou Z., Hultmark D. (2006) Immune pathways and defence mechanisms in honey bee Apis mellifera. Insect Molecular Biology 15(5): 645656. DOl: $10.1111 /$ j.1365-2583.2006.00682.x
Felicioli R., Garzelli B., Vaccari L., Melfi D., Balestreri E. (1997) Activity staining of protein inhibitors of proteases on gelatin-containing polyacrylamide gel electrophoresis. Analytical Biochemistry 244(1): 176-179.

Gorman M. J., Paskewitz S. M. (2001) Serine proteases as mediators of mosquito immune response. Insect Biochemistry and Molecular Biology 31: 257-262. DOl:10.1016/S0965-1748(00)00145-4

Grzywnowicz K., Ciokek A., Tabor A., Jaszek M. (2009) Profiles of the body-surface proteolytic system of honey bee queens, workers and drones: Ontogenetic and seasonal changes in proteases and their natural inhibitors. Apidolgie 40(1): 4-19. DOl: 10.1051/apido:2008057

Hadley N. F. (1981) Cuticular lipids of terrestrial plants and arthropods: a comparison of their structure, composition and waterproofing function. Biological Reviews 56: 23-47. DOl: 10.1111/j.1469-185X.1981.tb00342.x

Harmon A., VanEnglespdorp D. (2004) Beekeeping basics. College of Agricultural Sciences. Pennsylvania. Available at: http://pubs.cas.psu.edu/FreePubs/pdfs/agrs93. pdf

Haverty M. I., Thorne B. L., Page M. (1990) Surface hydrocarbon components of two species of Nasutitermes from Trinidad. Journal of Chemical Ecology 16(8): 2441 2449 .

Howard R., Lord J. (2003) Cuticular lipids of beeklouse, Liposcelis bostrychophila: hydrocarbons, aldehydes, fatty acids, and fatty acid amides. Journal of Chemical Ecology 29(3): 615-627.

Howard R. W., Blomquist G. J. (1982) Chemical ecology and biochemistry of insect hydrocarbons. Annual Review of Entomology 27: 149-172. DOl: 10.1146/annurev. en.27.010182.001053

Jackson L., Baker G. (1969) Cuticular lipids of insects. Lipids 5(2): 239-246.

Jacob J., Hanssen H. P. (1979) The chemical composition of cuticular lipids from dragonflies (Odonata). Zeitschrift für Naturforschung 34C: 498-502.

Jarau S., Schultz C., Hrncir M., Francke W., Zucchi R., Barth F. G., Ayasse M. (2006) Hexyl decanoate, the first trail pheromone compound identified in a stingless bee, Trigona recursa. Journal of Chemical Ecology 32: 1555-1564. DOI 10.1007/s 10886-006-9069-0 
Katzav-Gozansky T., Soroker V., Kamer J., Schulz C. M., Francke W., Hefetz A. (2003) Ultrastructural and chemical characterization of egg surface of honeybee worker and queen-laid eggs. Chemoecology 13: 129-134. DOI 10.1007/s00049-003-0238-0

Keeling C., Slessor K. N. (2005) A scientific note on the aliphatic esters in queen honey bees. Apidologie 36: 559-560. DOl: 10.1051/apido:2005044

Kolattukudy P. (1968) Biosynthesis of surface lipids. Biosynthesis of long-chain hydrocarbons and waxy esters is discussed. Science 159(3814): 498-505. DOl: 10.1126/ science.159.3814.498

Konopacka Z. (1999) Rasy pszczół w Polsce i ich użytkowanie. Pszczelarstwo 4: 5.

Laemmli U. (1970) Cleavage of structural proteins during the assembly of the head of bacteriophage T4. Nature 227: 680-685. DOl:10.1038/227680a0

Lavine B., Vora M. (2005) Identification of Africanized honeybees. Journal of Chromatography A 1096: 69-75.

Lavine B., Carlson D., Henry D., Jurs P. (1988) Taxonomy based on chemical constitution: Differentiation of Africanized honey-bees from European honey-bees. Journal of Chemometrics 2(1): 29-37.

Lee T., Lin Y. (1995) Trypsin inhibitor and trypsin - like protease activity in air - or submergence - grown rice (Oryza sativa L.) coleoptiles. Plant Science 106: 43-54. DOl: 10.1016/0168-9452(95)04058-3

Locke M., Krishnan (2008) The distribution of phenoloxidases and polyphenols during cuticle formation. Tissue and Cell 3(1): 103-126. DOl: 10.1016/S00408166(71)80034-4

Martin S. J., Jones G .R., Chãline N., Middleton H., Ratnieks F. L. (2002) Reassessing the role of the honeybee (Apis mellifera) Dufour's gland in egg marking. Naturwissenschaften 89: 528-532.

Merzendorfer H., Zimoch L. (2003) Chitin metabolism in insect: structure, function and regulation of chitin synthases and chitinases. The Journal of Experimental Biology 206: 4393-4412. D0l: 10.1242/jeb.00709

Muszyńska J. (1988) Fizjologiczne podstawy zimowania rodzin pszczelich. Puławy. 63 pp.
Nunes T., Morgan E., Drijfhout F., Zucchi R. (2010) Caste - specific cuticular lipids in the stingless bee Friesella schrottkyi. Apidologie 41: 579-588. DOl: 10.1051/apido/2010042

Olszewski K. (2007) Winter-hardiness of Buckfast bees under specific weather conditions of areas with alternating influences of maritime and continental climate. Journal of Apicultural Science 51(1): 73-82.

Olszewski K., Borsuk G., Paleolog J., Strachecka A. (2013) Validation of the methods of higienic behaviour evaluation in the honeybee. Medycyna Weterynaryjna 69(12): 749-752.

Österlund E. (1 983) Brother Adam and His Buckfast Bee. American Bee Journal 123(2): 85-88.

Paleolog J. (2009) Genetic-Environment Interactions Resulting from Different Levels of Competitiveness of Workers in Variuos Apis mellifera Breeds. Annals of Warsaw University of Life Sciences - SGGW 46: 101-108.

Patel S., Nelson D. R., Gibbs A. G. (2001) Chemical and physical analyses of wax ester properties. Journal of Insect Science 1(4): 1-7.

Pho B. D., Pennanec'h M., Jallon J. M. (1996) Purification of adult Drosophila melanogaster lipophorin and its role in hydrocarbon transport. Archives of Insect Biochemistry and Physiology 31: 289-303.

Plattner R., Spencer G. (1983) Chemical ionization mass spectrometry of wax esters. Lipids 18(1): 68-73.

SAS Institute SAS/STAT User's Guide release 9.13. Cary, NC, Statistical Analysis System Institute, license 86636, 2002-2003.

Schacterle G., Pollack R. (1973) A simplified method for quantitative assay of small amounts of protein in biological material. Analytical Biochemistry 51:654-655. PMID: 4735559

Schaner A. M., Dixon P. D., Graham K. J., Jackson L. L. (1989) Components of the courtship-stimulating pheromone blend of young male Drosophila melanogaster: (Z)-13tritriacontene and (Z)- 11 -tritriacontene. Journal of Insect Physiology 35(4): 341-345. 
Sonnet P. E., Uebel E. C., Lusby W. R., Schwarz M., Miller R. W. (1979) Sex pheromone of the stable fly. Identification, synthesis and evaluation of alkenes from female stable flies. Journal of Chemical Ecology 5(3): 353-361.

Stort A. C., Rebustini M. E. (1998) Differences in the number of some antennal sensilla of four honey bee (Apis mellifera) types and comparisons with the defensive behavior. Journal of Apicultural Research 37(1): 3-10. DOl: 10.1590/S0034-71081999000100020

Strachecka A., Gryzińska M., Krauze M. (2010) The influence of environmental pollution on the protective proteolytic barrier of the honey bee Apis mellifera's body surface. Polish Journal Environmental Studies 19(4): 855-859.

Strachecka A., Gryzińska M., Krauze M., Grzywnowicz K. (2011) Profile of the Body Surface Proteolytic System in Apis mellifera Queens. Czech Journal of Animal Science 56(1): 15-22.

Strachecka A., Paleolog J., Borsuk G., Olszewski K. (2012 a) Influence of formic acid on the body surface proteolytic system in different developmental stages of Apis mellifera L. workers. Journal of Apicultural Research 51(3): 252-262. DOl: 10.3896/IBRA. 1.51.3.06

Strachecka A., Paleolog J., Olszewski K., Borsuk G. (2012 b) Influence of amitraz and oxalic acid on the cuticle proteolytic system of Apis mellifera L. workers. Insects 3(3): 821-832. DOl:10.3390/insects3030821
Strachecka A., Borsuk G., Olszewski K., Paleolog J., Lipiński Z. (2012 c) Proteolysis on the body surface of pyrethroidsensitive and resistant Varroa destructor. Acta Parasitologica 58(1): 64-69.

Strachecka A., Borsuk G., Paleolog J., Olszewski K., Chobotow J. (2012 d) Anti-pathogenic activity on the body surface of adult workers Apis mellifera. Medycyna Weterynaryjna 68(5): 290-292.

Strachecka A., Borsuk G., Paleolog J., Olszewski K., Chobotow J., Skoczylas D. (2012 e) Body surface metalloproteases activity in Apis mellifera L. workers relative to environmental pollution. Medycyna Weterynaryjna 68(7): 406-410.

Strachecka A., Sawicki M., Borsuk G., Olszewski K., Paleolog J., Chobotow J. (2013) Acaricides as a method for fighting Varroa destructor mites in bee colonies - efficiency and risk. Medycyna Weterynaryjna 69(4): 219-224.

Sugumaran M. (2002) Comparative biochemistry of eumelanogenesis and the protective roles of phenoloxidase and melanin in insects. Pigment Cell Research 15: 2-9. DOl: 10.1034/j.1600-0749.2002.00056.x

Zou Z., Dawn Z. Z., Lopez D. L., Kanost M. R., Evans J. D., Jiang $H_{\text {. }}$ (2006) Comparative analysis of serine protease-related genes in the honey bee genome: possible involvement in embryonic development and innate immunity. Insect Molecular Biology 15(5): 603-614. DOl: $10.1111 / j .1365-2583.2006 .00684 . x$ 